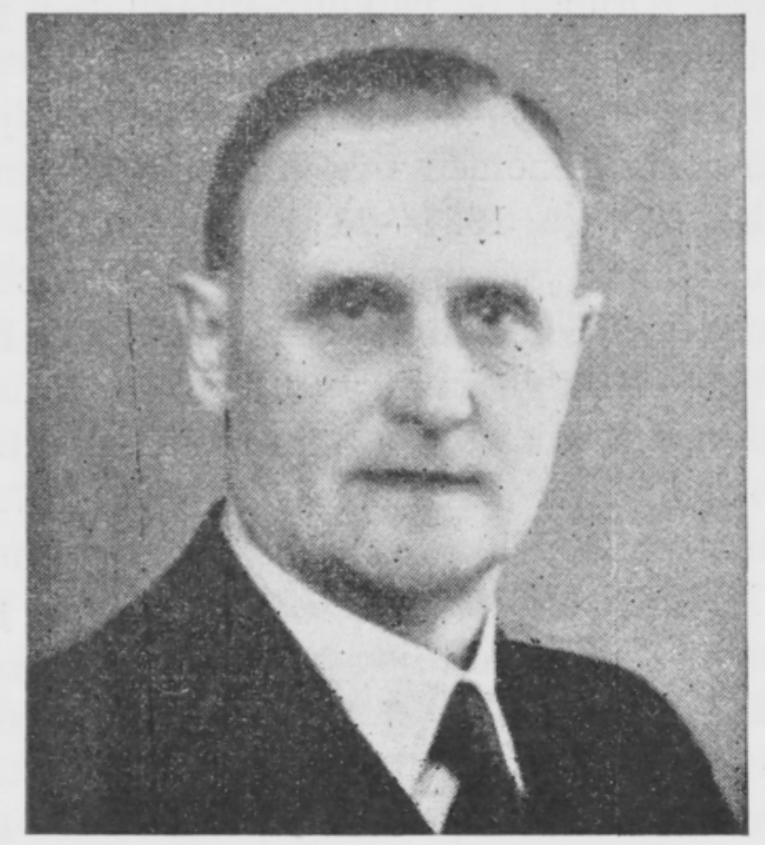

\title{
EEMELI KITUNEN
}

* 30. $8.1887-+5$. 10.1955

Valtion siementarkastuslaitoksen johtaja, professori Eemeli Kitunen syntyi 30. 8. 1887 Vehkalahdella, Etelä-Suomessa, lähti sisäisen tutkijahalun kannustamana opintielle oltuaan jonkin aikaa maanviljelijänä. Tällöin hän hankki itselleen hyvän käytännöllisen kokemuksen kasvinviljelytoiminnassa vastaisten tieteellisten tutkimustensa vankaksi perustaksi. Hän tuli ylioppilaaksi 1911, filosofiankandidaatiksi 1917, vihittiin filosofian maisteriksi 1919, suoritti fil. lisensiaatin tutkinnon 1922, vihittiin fil. tohtoriksi 1923. Hän oli Helsingin yliopiston dosenttina $1930-50$, sai professorin nimen ja arvon 1942. - Hänen tieteellinen koulutuksensa alkoi amanuenssina silloisen Maanviljelystaloudellisen koelaitoksen kasvitautiosastolla 1913 - 16 ja assistenttina samalla osastolla 1917-18. - Valtion väliaikaisen siementarkastuslaitoksen johtajana hän oli 1918-19 ja nimitettiin 1919 Valtion siementarkastuslaitoksen johtajaksi, jona hän toimi keskeytymättä 5. 10. 1955 tapahtuneeseen kuolemaansa asti.

Professori Kitusen laajaa tietoutta maatalouden alalla käytettiin monipuolisesti eri laitosten hyväksi. Niinpä hän oli Ilmatieteellisen keskuslaitoksen neuvotteleva jäsen 1925-50, maatalousministeriön edustaja Koetoimintayhdistysten liiton hallinnossa 1931-45, maatalouden koetoiminnan maanviljelysvaliokunnan jäsen ja puheenjohtaja 1926 - 36, samoin perunasyöpä-, viljantutkimus- ja hedelmäpuujaoston jäsen 1926 - 36, maatalouden koetoiminnan keskusvaliokunnan puheenjohtaja 1936 — 47, Viljan tutkimustoimikunnan puheenjohtaja 1954—55, Suomen edustajana Kansainvälisen siementarkastusliiton kongresseissa Cambridgessä 1924, Wageningenissa 1931, Tukholmassa 1934 ja Zürichissä 1937 sekä saman liiton 
tilintarkastaja v:sta 1924. Kitunen oli palkintolautakuntien jäsen ja puheenjohtaja monissa maatalousnäyttelyissä, Maatalousseurojen Keskusliiton asettamien kasvinsuojelu- ja kasvinviljelyvaliokuntien puheenjohtaja sekä viljelykasvilaatujen standardisoimisvaliokunnan jäsen, Suomen maataloustieteellisen seuran varapuheenjohtaja 1926-27, puheenjohtaja 1927-28, sihteeri 1928-32 ja saman seuran aikakauslehden toimituskunnan puheenjohtaja ja jäsen 1932-55, sekä kutsuttiin 1955 Suomen maataloustieteellisen seuran kunniajäseneksi. Hän oli myös Pohjoismaiden maataloustutkijain yhdistyksen Suomen osaston johtokunnan jäsen, useiden tieteellisten seurojen jäsen, Rikkihappo- ja Superfosfaattitehtaat Oy:n johtokunnan jäsen 1933 - 45 ja saman hallintoneuvoston jäsen 1946-47.

Kitunen julkaisi useita tieteellisiä julkaisuja ja kirjoituksia kasvinviljelyn ja kasvinsuojelun alalta. Näistä mainitakseni: „Kauran noesta ja sen hävittämisestä» (1916), " Jalostettujen kaura- ja ohralaatujen viljelyn leviämisestä meillä sekä muutamia päätelmiä enimmän viljeltyjen jalostettujen kaura- ja ohralaatujen menestymisestä oloissamme» (1920), "Tutkimuksia kauran nokisienistä ja eri kauralaatujen alttiudesta nokitartunnalle» (väitöskirja 1922), »Rotklee aus Finnland» (1925), „Om torkning av säd» (1929), „Kuoriutuneiden timotein siementen esiintyminen ja kylvösiemenarvo" (1929), "Kylvösiemen», teoksessa Maa ja Metsä (1929), "Rikkaruohot», samoin (1929), „Rikkaruohojen hävittäminen kemiallisin keinoin» (1930), „Untersuchungen über die Lebensweise des Haferbrandes Ustilago a ve na e (Persoon) Jensen» (1937), Valtion siementarkastuslaitoksen kertomukset 1919-1954 sekä suuren joukon kirjoitelmia edustamaltaan maatalouden ja sitä lähellä olevilta aloilta aikakaus- ja sanomalehdissä, kalentereissa yms.

Tutkimustyössään Kitunen kohdisti päähuomionsa kauran avonokeen (UstilagQ avenae), josta aiheesta hän väitteli tohtoriksi 1922. Laajassa väitöskirjatyössään hän selvitti tämän vahingollisen sienen merkitystä Suomessa ja elintapoja ja sen aiheuttamien vahinkojen torjuntakeinoja. Mainittakoon, että Kitusen väitöskirjan tutkimuksia on siteerattu $\mathrm{mm}$. tunnetussa P. Sorauerin perustamassa teoksessa "Handbuch für Pflanzenkrankheiten" (1932). Myöhemmässä työssään kauran avonoesta (1937) Kitunen käsittelee kiistanalaista kysymystä, millä tavoin sieni talvehtii. Tutkimuksissaan hän tulee siihen tulokseen, että toistaiseksi on itiöiden katsottava olevan ainoan kauran avonoen talvehtimistavan, eikä talvehtiminen tapahdu rihmastoasteella, kuten eräissä muissa julkaisuissa väitetään.

Kun vuosisatamme alussa siemenkaupan alalla sattuneet selkkaukset ja väärinkäytökset osoittivat silloisille maataloutemme johtomiehille ja maanviljelyksemme edistystä harrastaville sekä kunnollista kylvösiementä myymään pyrkivien liikkeiden johtajille, etteivät asiat kylvösiemenalalla olleet läheskään tyydyttävästi järjestetyt, vaikkakin 1901 annetussa asetuksessa oli annettu säännökset keinotekoisten lannoitusaineiden ja valmistettujen rehuvarain sekä siementavarain kaupasta. Annettu asetus oli sikäli puutteellinen, että se jätti kylvösiemenen ostajat kokonaan siementen myyjien armoille. Kun lisäksi ensimmäisen maailmansodan vuodet aiheuttivat puutetta ja hämminkiä siemenmarkkinoilla, niin järjestyksen aikaansaamiseksi tällä alalla ja siementutkimuksen tehostamiseksi perustettiin 1917 Valtion väliaikainen siementarkastuslaitos ja kun siementarkastuksen merkitys 
siemenkaupassa yhä enemmän selvisi yleisessä tietoudessa, niin tämän laitoksen jatkoksi perustettiin 4 päivänä heinäkuuta 1919 annetulla asetuksella Valtion siementarkastuslaitos, joka aloitti toimintansa seuraavan syyskuun ensi päivänä.

Toimintansa alkaneen Valtion siementarkastuslaitoksen johtajaksi onnistuttiin saamaan silloinen filosofian maisteri, sittemmin filosofian tohtori ja professori Eemeli Kitunen, joka oli ollut ensin apulaisjohtajana ja sitten johtajana aikaisemmin toimineessa valtion väliaikaisessa siementarkastuslaitoksessa. Tämä nimitys oli täydellinen täysosuma, sillä parempaa ja tehtäväänsä pystyvämpää miestä ei tälle tärkeälle paikalle olisi voitu saada. Sen ovat tapahtuneet tosiseikat osoittaneet ja sen on myös pakko kaikkien niiden todeta, jotka ovat joutuneet siemenasioissa tekemisiin prof. Kitusen ja Valtion siementarkastuslaitoksen kanssa.

Kitunen oli perehtynyt ennen opiskeluaan käytännön maatalouteen; hän oli perinpohjainen ja harkitseva tiedemies, josta on todisteena hänen runsas kirjallinen tuotantonsa; hän oli etevä organisaattori ja ennen kaikkea synnynnäinen johtaja.

Valtion siementarkastuslaitoksen toiminnan alkaessa Kitusen ensimmäinen tehtävä oli laitoksen ohjesäännön laatiminen. Siemenkaupasta annetut asetukset olivat puutteelliset. Jotta asiat saataisiin tällä alalla kuntoon, oli saatava sitovat määräykset siementavarain kaupasta. Niinpä eduskunnan päätöksen mukaan säädettiin laki siementavarain maahan tuonnista ja kaupasta. Laki vahvistettiin joulukuun 30 pnä 1919 ja tuli voimaan seuraavan vuoden alusta. Valtioneuvosto antoi tämän lain täytäntöönpanosta ja sovelluttamisesta päätöksen 1920. Nämä säännökset olivat Kitusen käsialaa sekä hänen harkintansa tulosta ja ne olivat pienin muutoksin voimassa vuoteen 1937, jolloin annettiin nykyisin voimassa oleva laki siementavarain maahan tuonnista, maasta viennistä ja kaupasta sekä asetus lain täytäntöönpanosta ja sovelluttamisesta, jotka molemmat niinikään olivat Kitusen laatimia. - V. 1919 vahvistettu laki turvasi jo täydellisesti kylvösiemenen ostajat väärinkäytöksiltä siemenkaupassa.

Nykyinen siemenkauppalakimme poikkeaa edeltäjästään vain eräin kohdin: siihen on otettu siemenkaupan valvonnan helpottamiseksi määräykset siementä myyvien liikkeiden ilmoitus- ja siemenkaupan kirjanpitovelvollisuudesta sekä, että jokainen myytävä siemenerä, pieninkin on varustettava vakuustodistuksella, joka perustuu Valtion siementarkastuslaitoksen siementavaraerästä virallisesti otetun näytteen tutkimustulokseen $\mathrm{j}$ a on $\mathrm{t}$ ä mä tarkast us n umero myös mainittava vaku ustodistuksessa. Vain koristekasvien siemenet tekevät tässä suhteessa poikkeuksen, kun niitä myydään pienemmissä kuin kilon erissä. Tämän lain määräys, Valtion siementarkastuslaitoksen tarkastusnumeron pakollinen maininta vakuustodistuksessa, on sangen pitkälle menevä, ja tietääkseni tällaista määräystä ei ole minkään maan siemenkauppalaissa koko maailmassa. Tällaisen pitkälle menevän valtion johteisen määräyksen ottaminen siemenkauppalakiimme on omansa todistamaan sitä ehdotonta luottamusta, jota Kitunen ja hänen kauttaan koko Valtion siementarkastuslaitos silloin nautti lainsäätäjien taholta.

Rinnan siementarkastuslaitoksen kasvun ja työmäärän lisääntymisen kanssa Kitunen loi ja kehitti laitoksen työ- ja tutkimusmenetelmät tieteellisesti täysin 
päteviksi ja kansainvälisen mitan täyttäviksi. Asiantuntijan on pakko tunnustaa niiden eräissä kohdin tarkkuudessa ne ylittävänkin.

Tasapuolisena, harkitsevana ja lakia sekä oikeutta noudattavana miehenä Kitunen saavutti siemenliikkeiden johtajien ja muiden siementarkastuslaitoksen kanssa kosketuksiin tulleiden henkilöiden niin maataloustiedemiesten kuin käytännön viljelijäinkin täydellisen luottamuksen. Siemenkauppalain noudattamista valvottiin hänen johdollaan tehokkaasti ja kaikkien siemenliikkeiden kohdalta puolueettomasti, mutta kuitenkin tarkoin lakiin perustuen.

Perinpohjaisen kasviopillisen ja tarkan saksalaisen alkukoulutuksen saaneena siementutkijana Kitusen oli verraten vaikea mukautua uuteen kansainvälisessä siementarkastuskongressissa Dublinissa 1953 lopullisesti hyväksyttyyn ns. nopeaan siementen puhtausmäärittelyyn, jossa puhtaaksi siemeneksi katsotaan puoliskoa isompi osa särkyneestä siemenestä, katsomatta ensinkään onko siinä alkiota vai ei ja kehittyykö siitä itua vai ei; idätyskoe sitten ratkaisee itääkö siemen vai ei. Hän piti tätä taka-askeleena siementen tutkimisessa, joskin menetelmä nopeutti puhtauserittelyä ja tuotti siten runsaasti ajan säästöä. Joustavana ja avarakatseisena hän totesi, että tähän oli mukauduttava.

Kitunen oli kotimaassaan niin tunnettu, että hänet ja siementen tutkiminen sekä siementarkastuslaitos rinnastettiin. Erikoista arvonantoa ja kunnioitusta Kitunen nautti johtamansa laitoksen henkilökunnan taholta. Hän oli maltillinen, pitkämielinen ja ymmärtäväinen jokaista kohtaan oikeamielinen ja puolueeton. Hänellä oli kaiken johtotähtenä käsityksensä mukainen laitoksen ja henkilökunnan paras. Kansainvälisestikin Kitunen oli tunnettu ja arvostettu ja oli mm. vuodesta 1924 yhtäjaksoisesti kansainvälisen siementarkastusliiton tilien tarkastaja osallistuen liiton moniin kongresseihin ja eri valiokuntien työskentelyyn.

Eemeli Kituseen voidaankin täysin oikeutetusti soveltaa hänen omat sanansa, jotka hän esitelmässään maatalousviikolla jo v. 1920 eli yli 36 vuotta sitten lausui: "Ylipäänsä on tutkimuslaitosten ja kaiketi myöskin muiden laitosten toiminta melkoisessa määrin riippuvainen niistä henkilöistä, jotka laitoksen toimintaa ohjaavat. Mitä lahjakkaampia ja työkykyisempiä ohjaajat ovat sitä paremmin laitos toimii ja sitä pysyväisempiä hedelmiä sen toiminta tuottaa.» Tämä pitää erikoisesti paikkansa Kituseen ja hänen johtamaansa Valtion siementarkastuslaitokseen nähden.

Kitunen oli erikoisen hyvä ja tasapuolinen ihminen. Hän oli toveripiirissä varsin pidetty humorinsa ja toisia vaikeissakin olosuhteissa ymmärtävän luonteensa tähden. Hän oli synnynnäinen johtaja ja tiedemies, jonka poismeno on raskas menetys koko maamme maataloudelle, sen kasvinviljelylle ja erikoisesti hänen johtamalleen laitokselle.

\section{J. E. Aalto-Setälä}




\section{EEMELI KITUNEN \\ * 30. 8. $1887-+5.10 .1955$}

The Director of the State Seed Testing Station, Professor Eemeli Kitunen, was born on 30th August 1887 at Vehkalahti in South Finland, and started his studies after having been for some time a farmer. By then he had acquired plenty of practical experience in plant husbandry which was later to form a firm basis for his scientific investigations.

He matriculated in 1911, took his B. A. in 1917, and was conferred the degree of M. A. in 1919. In 1922 he took the examination of Lic. Phil. and was conferred the degree of Dr. Phil. in 1923. He was docent at the University of Helsinki in $1930-50$ and was granted the title and rank of professor in 1942.

He began his scientific training as amanuensis in 1913-16 at the Division of Plant Pathology of the Agricultural-Economic Experimental Institute of that time, and was assistant of the same institute in 1917-18. In 1918-19 he was director of the Temporary State Seed Testing Station and, in 1919 was appointed director of the State Seed Testing Station, where he worked until his death on 5th October 1955.

Professor Kitunen's extensive knowledge in the field of agriculture was used in many ways for the benefit of different institutions. Thus he was a consulting member of the Meteorological Office of Finland 1925-50, the representative of the Ministry of Agriculture on the Direction of the Union of the Associations for Experimental Activity in 1931-45, a member and the chairman of the Agricultural Commission of the Central Board of Agricultural Research in 1926-36, further he worked on Commissions for Potato Wart Disease, Cereal Research, and Fruit Trees in 1926 - 36, he was chairman of the Central Board of Agricultural Research in 1936-47 and chairman of the State Board for Cereal Research in 1954-55. He represented Finland at congresses of the International Seed Testing Association at Cambridge 1924, at Wageningen 1931, at Stockholm 1934, and at Zürich in 1937, and was the auditor of the same Association from the year 1924. Professor Kitunen was member and chairman in price commissions at many agricultural shows chairman of the Boards for Plant Protection and Plant Husbandry put up by the Association of Agricultural Societies, member of the Commission for Standardization of Cultivated Plants, vicechairman of the Scientific Agricultural Society of Finland in $192 €-27$, its chairman in 1927 - 28, its secretary in 1928 - 32, 
and member and chairman of the editorial staff of the journal published by the same society in 1932-1955. In 1955 he was elected honorary member of the Scientific Agricultural Society of Finland. He was also member of the Direction of the Finnish Division of the Association of Research Workers in the Northern Countries, member of many scientific societies, member of the Direction of Rikkihappo- \& Superfosfaattitehtaat Oy [Sulphuric Acid \& Superphosphate Work Company] in 1933 - 45 and member of the administrative board of the same firm in 1946 - 47.

Kitunen published many scientific publications and articles in the field of plant husbandry and plant protection. Of these may be mentioned: "Kauran noesta ja sen hävittämisestä» (1916) [On the smut of oats and its destruction], "Jalostettujen kaura- ja ohralaatujen viljelyn leviämisestä meillä sekä muutamia päätelmiä enimmän viljeltyjen jalostettujen kaura- ja ohralaatujen menestymisestä oloissamme» (1920) [On the distribution of the cultivation of bred oat and barley varieties in Finland and some conclusions concerning the thriving of the most cultivated bred oat and barley varieties in our conditions], "Tutkimuksia kauran nokisienistä ja eri kauralaatujen alttiudesta nokitartunnalle» (Väitöskirja 1922) [Investigations on smut fungi of oat and on the susceptibility of different oat varieties to smut disease, Dissertation 1922], "Rotklee aus Finnland» (1925) [Red clover from Finland], "Om torkning av säd" (1929) [On the drying of seed], "Kuoriutuneiden timotein siementen esiintyminen ja kylvösiemenarvo" (1929) [Occurrence and seed value of hulled timothy seed], "Kylvösiemen" (1929) [The seed], "Rikkaruohot» (1929) [Weeds], "Rikkaruohojen hävittäminen kemiallisin keinoin» (1930) [Destroying of weeds by chemical means] "Untersuchungen über die Lebensweise des Haferbrandes Ustilago avenae (Persson) Jensen" (1937) Investigations on the smut of oats Ustilago avenae and its biology], Reports of the State Seed Testing Station in 1919-54 and numerous articles in the field of agriculture in periodicals, newspapers, calendars etc.

Kitunen did extensive research work on the smut of oat (Ustilago avenae) on which he wrote his Doctor's thesis in 1922. He explained the significance and biology of this noxious fungus in Finland and dealt with the means to control its damage. These investigations are inter alia cited in the well known handbook by P. Sorauer: Handbuch für Pflanzenkrankheiten (1932). In his later investigations on the smut of oat (1937) Kitunen deals with the disputed problem of the overwintering of this fungus and concludes that for the present the spores must be considered the only way of overwintering of the Ustilago avenae and that overwintering does not occur in the hyphal stage as stated in some publications.

At the beginning of the century the discrepancies and misuse in the sale of seed showed to the leaders of our agriculture and to those interested in the progress of our agriculture as well as managers of seed firms, who wanted to sell good seed, that the situation in the seed trade was far from satisfactory despite the regulations in the statute of 1901 on the sale of fertilizers, feeding stuffs and seed, which in fact left the buyers of seed at the mercy of the seed selling firms. When further the years of the first world war caused a shortage and confusion in the seed market, the Temporary State Seed Testing Station was founded to establish order and 
to increase the efficiency of seed investigation. With the significance of seed inspection in seed trade becoming increasingly obvious, it was decided to continue the Seed Testing Station as a permanent institution and the necessary law was passed July 4th 1919. The Station began its activities on September 1st 1919.

The State Seed Testing Station appointed as director Eemeli Kitunen who had been assistant director and director of the Temporary State Seed Testing Station. This appointment proved an excellent choice as it would not have been possible to find a better and more capable man than Kitunen.

Professor Kitunen was a person with a practical turn of mind as well as a thorough and genuine scientist with numerous scientific works to his credit. He was a skilled organizer, but above all, a born leader.

The first task for Kitunen was to establish the rules for State Seed Testing Station. The statutes concerning seed commerce were incomplete and it was very necessary to lay down permanent regulations for the seed trade. The Diet decided to pass a law concerning the sale and import of seeds and the law was ratified on 30th December 1919. These regulations were planned by Kitunen and the law remained with few changes valid until the year 1937, when the new law concerning the export, import and commerce of seeds which is valid today was passed. The law and the statute on its execution and application were drafted by Kitunen. The law on seed commerce (1919) gave complete protection to buyers of seed against any misuse in seed commerce.

The present law concerning seed commerce deviates from the earlier law very little. To facilitate the control of seed commerce it contains stipulations for seed selling firms about granting information and about bookkeeping duties, and a decision that all seed that is sold however small the amount, must have a certificate which is based on the results of investigations of samples taken officially from the seed by the State Seed Testing Station. The number of this testing must also be mentioned in the certificate. Only the seed of ornamental plants forms an exception as it is sold in quantities less than $1 \mathrm{~kg}$. The stipulation that the testing number of the State Seed Testing Station must also be mentioned in the certificate is very far reaching, and so far as I know no other law on seed commerce in the world includes such an order, but it shows that the officials had absolute confidence in Kitunen, and the State Seed Testing Station.

As an impartial meticulous and law-abiding person Kitunen won the confidence of the directors of seed firms and of all those who came into contact with the State Seed Testing Station. Under Kitunen's leadership the strict observance of the seed commerce law was efficiently and impartially supervised.

With his profound and exact training in seed testing it was somewhat difficult for Kitunen to adjust himself to the new "quick method for determination of purity of seeds» accepted at the International Congress for Seed Testing at Dublin in 1953, where a part of a broken seed which is bigger than one half is considered a pure seed irrespective of whether it contains an embryo or not, or whether it develops a sprout or not. The germination test later decides if the seed will germinate or not. Kitunen considered this a step backwards in seed research, although the method 
enabled tests of purity to be made quicker and saved much time. In his far-sighted way, he however realised its positive value and came to accept it.

In this country Kitunen soon came to be identified into the State Seed Testing Station. The personnel of the State Seed Testing Station esteemed him high for his patience and understanding, his objective mind and sense of humor.

In his lecture during the agricultural week 1920 Eemeli Kitunen said: "The work of research institutes and also other institutions depends to a great extent on their directors. The more talented and the more capable the directors are, the better the institute works and the more permanent are the fruits of its activity." These words can with justice be applied to Kitunen himself.

J. E. Aalto-Setälä 